\title{
IDARI YARGILAMA HUKUKUNDA KANUN YOLUNA BAŞVURU HAKKININ ANAYASAL GÜVENCEYE SAHIP OLMASI BAKIMINDAN ELE ALINMASI
}

\author{
Ekin SEVINÇ*
}

\begin{abstract}
$\ddot{O} Z$
Ilk derece mahkemeleri tarafindan verilen kararlarin hukuka uygun olup olmadıklarının denetimi amacına hizmet eden başvuru yollarına, yargılama usulleri sisteminde kanun yolu adı verilmektedir. Idari yargıda kanun yolları, İdari Yargılama Usulü Kanunu'nun 'Kararlara Karşı Başvuru Yolları” başlı̆̆ını taşıyan 45. ve devamı maddelerinde düzenlenmiştir. Illgili maddelere bakıldığında, ilk derece mahkemeleri tarafindan verilen ve belli miktara kadar olan bazı uyuşmazlıklara karşı kanun yolunun kapalı olduğu görülmektedir. Temelde, davaların hızlandırılması, mahkemelerin iş yükünün azaltılması gibi gerekçelerle kimi kararlara karşı kanun yolunun kapatılmasının, kamu yararının gerektirmesi halinde kanun koyucunun takdir yetkisi içinde olduğu kabul edilmektedir. Ancak, hali hazırda yargl yolunun varlığının yanında, kimi kararlara karşı kanun yoluna gidilemeyecek olmasının Anayasa'ya; dolayısıyla, hukuka aykırılık teşkil edip etmeyeceğinin tespitini de yapmak gerekmektedir. Bu doğrultuda makalenin de temel amacı, kanun yoluna başvuru hakkının varlı̆̆ııın sınırlanmasının mümkün olup olmadığı; şayet mümkün ise, bu sınırlamanın sınırında kullanılabilecek ölçütlerin neler olduğunu ortaya koymaktır.
\end{abstract}

Anahtar Kelimeler: İdari Yargllama Hukuku, Kanun Yolu, Dereceli Yargllama, Hukuk Devleti İlkesi, Hak Arama Özgürlüğ̈̈.

\section{A DISCUSSION ABOUT THE RIGHT TO APPEAL FOR HAVING CONSTITUTIONAL GUARANTEE IN ADMINISTRATIVE JURISDICTION}

\section{ABSTRACT}

The remedies that serve the purpose of auditing whether the adjudgment given by the courts of the first instance are in accordance with the law are called the remedy in the system of judicial procedures. The remedies in administrative jurisdiction are regulated in articles 45 and the rest of the law on administrative procedure system that partaking under the head of ways against adjudgment. When the relevant articles

\footnotetext{
* Arş. Gör., Trabzon Üniversitesi Hukuk Fakültesi, İdare Hukuku Anabilim Dalı, e.posta: ekinaliolu@gmail.com

ORCID ID: 0000-0002-5483-425X

DOI : 10.34246/ahbvuhfd.775434

Yayın Kuruluna Ulaştığı Tarih $\quad$ : 29/01/2020

Yayınlanmasının Uygun Görüldüğü Tarih: 03/06/2020
}

Ankara Hacı Bayram Veli Üniversitesi Hukuk Fakültesi Dergisi C. XXIV, Y. 2020, Sa. 3421 
are examined, it is seen that the legal remedy against some dispute up to a certain amount given by the courts of the first instance is closed. Basically, it is considered that legislator is in discretion if the public weal requires the closure of the remedy against certain adjudgment, such as accelerating cases and reducing the workload of the courts. However, in addition to the existence of the judicial remedy, there is no way to go against the law against some adjudgments that are not subject to the constitution; Thus, it is necessary to investigate whether it will constitute a violation of the law. In this respect, this article aims to investigate whether it is possible to limit the existence of the right to remedy, if it is possible, to determine what criteria can be used to limit this limitation.

Key Words: Administrative Procedure System, Legal Remedies, Graded Trial, Principle of the State of Law, Right to Legal Remedies.

\section{GíRiş}

İlk derece mahkemeleri tarafından bir kararın verilmesi, yargılamanın tamamen sona erdiği anlamına gelmemektedir. Kanunlar, bir denetim muhakemesi olanağı tanımış ve taraflar da bundan yararlanmak suretiyle üst mahkemeye başvuru hakkını kullanmışlar ise, kanun yolları evresi denilen ve bu bakımdan dereceli bir yargılama mekanizmasını ortaya çıkaran, yargılamada yeni bir evre başlamaktadır. ${ }^{1}$ Hukuk sistemleri, yargısal kararlardaki hataların en aza indirilmesi için üst mahkemeye başvurma imkanını genel olarak düzenlemektedir. Ancak kimi kanunlarda, ilk derece mahkemesi kararlarına karşı kanun yoluna müracaat hakkı taraflara tanınmamaktadır. Nitekim çeşitli yargı kollarında, ilk derece mahkemelerince verilmiş bulunan bazı kararlara karşı kanun yoluna başvuru imkanı kanun ile kaldırılmıştır. Başka bir ifadeyle, bu kararlar verildikleri an kesin hüküm halini almaktadır. Bu kararlar idari yarg1 için 2577 say1lı İdari Yargılama Usulü Kanunu madde 45/1'de, ceza yargılaması için 5271 sayılı Ceza Muhakemesi Kanunu madde 272/3'te, hukuk yargılaması için ise, 6100 sayılı Hukuk Muhakemeleri Kanunu madde 341/2'de düzenleme altına alınmıştır.

Anayasa'nın hak arama hürriyeti başlıklı 36. maddesi, herkese meşru vasita ve yollardan faydalanmak suretiyle yarg1 mercileri önünde davac1 veya davalı olarak iddia ve savunma ile adil yargılanma hakkı tanımaktadır. Dolayısıyla, hak arama özgürlügü ile adil yargılanma hakkı temel hak ve

1 ÖZTÜRK, s. 537.

422 Ankara Hacı Bayram Veli Üniversitesi Hukuk Fakültesi Dergisi C. XXIV, Y. 2020, Sa. 3 
özgürlükler arasında yer almaktadır. Acaba anayasal bu hükmün içeriğini yalnızca ilk derece mahkemeleri önünde yapılan yargılama mı oluşturmaktadır? Yoksa, kanun yoluna başvurma hakkı da hak arama özgürlügünün kapsam1 içerisinde değerlendirilebilir mi? Başka bir ifadeyle; taraflara, aleyhlerinde verilen ve henüz kesinleşmemiş bir yargısal kararı üst derece mahkemesinde denetletme imkanı tanımak bakımından hukuki çareler ${ }^{2}$ olan kanun yoluna başvurma hakkı, hak arama özgürlüğünün kapsamına dahil midir? Çalışmanın konusunu, esas olarak bu hükümden ve ilgili diğer anayasal düzenlemeler ile ilkelerden yola çıkarak dereceli yargılamanın anayasal bir hak olup olmadığını saptamak; şayet buna olumlu yanıt verilecek olursa, kimi kararlara karşı kanun yoluna başvuru hakkının tanınmamasının söz konusu Anayasal ilkelere ne derece uyumlu olduğunu ortaya koymaktır.

\section{KANUN YOLU KAVRAMI VE AMACI}

Yarg1 faaliyetleri, insan eliyle yürütülen ve insanı merkezine alan bir faaliyet olduğu için, doğası gereği yargı kararlarının hatalı ya da noksan olma ihtimali her daim bulunmaktadır. Devletin diğer erkelerinden farklı olarak daha tarafsız ve bağımsız bir yapısının bulunması, verilen kararların telafisinin başka bir erk tarafindan mümkün olmaması, kimi zaman başvurulacak son merci olması gibi sebeplerle en az hatanın yargı alanında gerçekleşmesi gerekmektedir. ${ }^{3} \mathrm{Bu}$ ise, yargı mercileri tarafından verilen kararlara karşı duyulan güvenin artmasını sağlamaktadır. Ancak kararları veren hakimler de insandır ve hata yapabilmeleri mümkündür. Kimi zaman iş yoğunluğu nedeniyle yeterince araştırma ve inceleme faaliyetinde bulunmamalarından, kimi zaman yeterli bilgi birikimi ya da tecrübeye sahip olmamalarından dolay1 hatalı ya da eksik kararlar verebilmeleri söz konusu olabilmektedir. Öte yandan yargılama faaliyeti neticesinde verilen kararlarda hata bulunmamakla birlikte, aleyhine karar verilen tarafın kendi haklılığına olan inancına göre kararın hatalı olduğu iddiası da ileri sürülebilir. ${ }^{4}$ Söz konusu ihtimaller, kişilerin bir yargılama faaliyetinden beklentilerinin ne olduğu ile ilgilidir. Yargılamanın, davanın açıldığı ve nihai kararın verildiği derece mahkemesinde sona ermeyip; verilen kararın denetimi için kanun yolu başvurusu çerçevesinde üst mahkemeye taşınması, kişilerin yargılama faaliyetinden beklentilerinin sağlanması amacına da hizmet etmektedir.

\footnotetext{
2 AIANGOYA/YILDIRIM/DEREN YILDIRIM, s. 445.

3 PEKCANITEZ/ÖZEKES/AKKAN/KORKMAZ, s. 2150.

4 ODYAKMAZ, s. 5.
} 
İzah edilen olasılıklardan doğan ihtiyaçların karşılanması göz önüne alınarak kabul edilmiş olan kanun yolu sistemi; tarafa, kendi aleyhine olan ve henüz kesinleşmemiş bir yargı kararının bir üst derece mahkemesinde incelenmesi ve eğer varsa karardaki hukuka aykırılıkların giderilmesi imkanını veren bir usuldür. ${ }^{5}$ Kanun yolu kavramının genel ifadesi bu şekilde olmakla birlikte; doktrinde, kanun yolunun geniş ve dar anlamda olmak üzere iki farklı şekilde tanımlandığı görülür. Geniş anlamda kanun yolu, mahkemelerin vermiş oldukları bütün kararların, nihai karar ve ara karar da dahil olmak üzere, denetlenmesini sağlayan her türlü incelemedir. Dar ve teknik anlamda kanun yolu ise, mahkemelerin yalnızca işten el çekmesi sonucunu doğuran nihai kararlarının denetiminin yapılmasıdır. ${ }^{6}$ Türk Hukuku'nda kanun yolu, dar ve teknik anlamıla kabul edilmektedir.

Nihai kararlara karşı kanun yoluna başvurma hakkının kabulüyle, hem mahkemeler tarafindan verilen kararların hukuka uygun olarak verilip verilmediğinin denetimi yapılarak kararların ilgili tarafı tatmin etme olanağ sağlanmış olur hem de benzer hukuki olaylarda verilen kararlar arasında birlik sağlanarak toplumda hukuka olan güvenin yerleşmesine katkıda bulunulur. ${ }^{7}$ $\mathrm{Bu}$ bakımdan, kanun yolunun iki temel amacının olduğu görülür: $\mathrm{Bu}$ amaçlardan ilki, somut uyuşmazlık hakkında mahkeme tarafından verilen karar bakımından maddi gerçekliğin elde edilmesini ve bu suretle kişiler açısından adaletin sağlanmasını mümkün kılmaktır. Dolayısıyla, kanun yolu vasıtasıyla taraf menfaatinin yerine getirilmesi sağlanır. ${ }^{8}$ Mahkeme kararlarındaki hataların en aza indirilebilmesi amacıyla, kararların kesinleşmesinden önce bir üst mahkeme tarafından denetlenmesi kanun yolu ile mümkün olmaktadır. Dolayısıyla kanun yolu, mahkemelerce verilen hükümlerin doğruluğunun garantisi olup, somut olayda adaletin gerçekleştirilmesini sağlamaktadır. Bununla birlikte, kararların denetleneceğini bilen ilk derece mahkemelerinin daha dikkatli ve doğru kararlar vermelerini de sağlamak adına kanun yolunun etkisi bulunmaktadır. Dolayısıyla kanun yolları sayesinde, yargılama faaliyetinin kalitesi artırılmış olmaktadır. ${ }^{9}$

Kanun yolunun bir diğer amacı, hukukun uygulanmasında birlik sağlanması ihtiyacıdır. Hakimlerin benzer somut olaylara uygulayacakları hukuk kurallarını, kendi anlayışlarına göre başka başka biçimlerde

\footnotetext{
5 ÜSTÜNDA $\breve{G}$, s. 816; ALANGOYA/YILDIRIM/DEREN YILDIRIM s. 445.

6 BILLGE, s. 3.

7 BİLGE, s. 6.

8 ÇİFTÇI, s. 7-8.

9 DEREN YILDIRIM, s. 4 vd.
}

424 Ankara Hacı Bayram Veli Üniversitesi Hukuk Fakültesi Dergisi C. XXIV, Y. 2020, Sa. 3 
yorumlamaları mümkündür. $\mathrm{Bu}$ durum ise, benzer hukuki olaylarda mahkemelerin farklı kararlar vermelerine neden olabilmektedir. Hukuk kurallarının taraflara eşit şekilde uygulanmaması suretiyle verilen kararlar, toplumda adalete olan güveni zedelemektedir. Kaldı ki mahkeme kararları arasındaki bu farklılıklar, kanun önünde eşitlik ilkesini de zarara uğratmaktadır. $\mathrm{Bu}$ nedenle mahkemeler tarafından, benzer hukuki olaylarda verilen kararlar arasında birliği sağlama zorunluluğu ortaya çıkmaktadır. Kanun yolu denetimi ise, uygulamada birliği sağlayan ve bu bakımdan sadece bireysel menfaate yönelik olarak değil, toplum için de güvence sağlayan en önemli araçtır. ${ }^{10}$

Kanun yolu kavramının tanımı ve amaçları bu şekilde olmakla birlikte, mahkeme kararına karşı yapılacak bir başvurunun kanun yolu vasfinı taşıması için iki karakteristik özelliğin bulunması gerekir. Bunlar erteleyici etki ve aktarıcı etkidir. Erteleyici etki, kanun yoluna başvurunun ilk derece mahkemesinin nihai kararının şekli anlamda kesinleşmesinin ve hukuki uyuşmazlığın sona ermesinin engellenmesidir. ${ }^{11}$ Aktarıcı etki ise, kanun yolu incelemesinin bir üst mahkeme tarafından yapılması anlamına gelmektedir. Başka bir ifadeyle, uyuşmazlığın bir üst yargı merciine aktarılması ve orada tekrar incelenmesi aktarıcı etkidir. Bu halde kanun yoluna başvuru üzerine yapılacak inceleme, uyuşmazlık hakkında ilk kararı veren hakim tarafından değil; farklı bir hakim tarafından yerine getirilecektir. ${ }^{12}$ Aksi halde söz konusu başvuru, teknik anlamda dereceli yargılama sayılamayacaktır.

Dereceli yargılamanın Türk İdari Yarg1 Sistemi’ndeki görünümü 1982 yılından önceki durum, 1982 yılı itibariyle ortaya çıkan durum ve 2014 yılından sonraki durum olmak üzere farklı şekillerde karşımıza çıkmaktadır. 1982 yılından önceki dönemde 1961 Anayasası ve 521 sayılı Danıştay Kanunu'na göre Danıştay, bazı idari uyuşmazlıkları hem ilk derece hem de üst derece yargı merci olarak çözüme kavuşturmaktaydı. Bazı idari uyuşmazlıklar ise, mahkeme niteliğinde olmayan ancak yargılama yetkisi bulunan il idare kurulları, vergi itiraz ve temyiz komisyonları, gümrük hakem heyetleri gibi kurullarca çözümleniyor, bunların verdikleri kararlara karşı da Danıştay’a gidilebiliyordu. Dolayısıyla bu dönemde, dereceli bir yargılamanın varlığından söz etmek mümkün görünmemekteydi. ${ }^{13}$

\footnotetext{
10 YILDIRIM/YASIN/KAMAN/ÖZDEMIR/ÜSTÜN/OKAY TEKINNSOY, s. 879-880.

11 AKKAYA, s. 57.

12 AKKAYA, s. 61.

13 GÖZÜBÜYÜK/TAN, s. 64
} 
1982 yılı itibariyle, idari yargıya ilişkin üç temel kanun kabul edilmiştir. Bunlar: 2575 sayılı Danıştay Kanunu, 2576 sayılı Bölge İdare Mahkemeleri, İdare Mahkemeleri ve Vergi Mahkemelerinin Kuruluşu ve Görevleri Hakkında Kanun ile 2577 sayılı İdari Yargılama Usulü Kanunu. Söz konusu kanunların kabul edilmesiyle ilk derece idare ve vergi mahkemeleri kurularak Danıştay, özel görevli ilk ve son derece mahkemesi ve ilk derece mahkemesi kararlarının temyiz yolu ile denetiminin yapıldığı yüksek mahkeme durumuna getirilmiştir. İlk derece mahkemelerinin bazı nihai kararlarını itiraz yolu ile incelemek üzere bölge idare mahkemeleri kurulmuştur. 1990 yılında 3619 sayılı Kanun ile Danıştay Kanunu'nda, 3622 sayılı Kanun ile de İdari Yargılama Usulü Kanunu'nda değişiklik yapılarak Danıştay dava dairelerinin ilk derece mahkemesi sıfatıyla verdiklerin kararların da Danıştay içinde temyiz edilebilmesi imkanı getirilmiştir. Böylelikle idari yarg1 yerlerinin tümü iki dereceli bir sistem üzerine kurularak dereceli yargılamanın esasları benimsenmiştir. ${ }^{14}$

2014 yılında 6545 sayılı Türk Ceza Kanunu ile Bazı Kanunlarda Değişiklik Yapılmasına Dair Kanun ile idari yargıda itiraz kanun yolu kaldırılmış, istinaf kanun yolu kabul edilmiştir. Böylelikle, değişen hükümlerle birlikte artık ilk derece mahkemeleri kararlarına karşı itiraz kanun yolu değil, istinaf başvurusu yapılabileceği hüküm altına alınmıştır. Bölge idare mahkemelerinin istinaf incelemesi neticesinde verdiği kararlardan ise, İdari Yargılama Usulü Kanunu madde 46 kapsamında sayılanlar için temyiz kanun yoluna başvuru imkanı getirilmiştir. Böylece dereceli yargılama bakımından idari yargı sistemimiz genel olarak iki; bölge idare mahkemeleri tarafindan verilip de temyiz kanun yolunun açık olduğu belirtilen kararlar bakımından, üç dereceli yargı sistemi durumuna gelmiştir.

Kanun yolu, kararlardaki hataların giderilmesi ve hukuk kurallarının uygulanmasında birliğin sağlanması amacının yerine getirilmesine hizmet ettiğinden bu amacın gerçekleştirilebilmesi, kararı veren dışında başka bir merci tarafindan denetimin yapılması ile mümkün olabilmektedir. $\mathrm{Bu}$ bakımdan, kararı veren dışındaki bir merciin yapacak olduğu denetim, taraflar açısından da güvence teşkil etmektedir. İdari yargılama hukuku açısından ise, 6545 sayılı Kanun ile idari yargıda yapılan değişiklikler neticesinde mülga olan karar düzeltme müessesesinin bu bakımdan teknik anlamda bir dereceli yargılama sayılması mümkün görünmemekteydi. Danıştay dava daireleri ile

${ }^{14}$ GÖZÜBÜYÜK/TAN, s. 66-67. 
idare ve vergi dava daireleri kurullarının temyiz incelemesi ile bölge idare mahkemelerinin itiraz üzerine verdiklerin kararların, yine aynı mercilerde tekrar incelenmesi anlamına gelen karar düzeltmesi müessesesinin, hem kanun yolunun teknik anlamındaki zayıflığı hem de kararın, verildiği yargı yeri tarafından yeniden incelenecek olmasının bir anlam ifade etmeyeceği psikolojisi, kanun yollarından beklenen güvenceyi sağlamaktan uzak görünmekte; dolayısıyla, dereceli yargılamanın bir örneği olarak sayılmaması gerekmektedir. ${ }^{15}$

\section{DERECELII YARGILAMANIN ANAYASAL BİR HAK OLUP OLMADIĞI MESELESİ}

\section{A. Genel Olarak}

Yukarıda izah edildiği üzere, bir hukuk sisteminin yargılama usullerinde kanun yollarının düzenlenmesi, taraflara bu usuli imkanların tanınması son derece önemlidir. Bu imkan aynı zamanda dereceli yargılama ilkesiyle açıklanmaktadır. Yargılama usulünde kanun yoluna başvurma hakkının sağlanması, o hukuk sisteminde dereceli yargılamanın kabul edildiği anlamına gelmektedir. Dereceli yargılama esasen mahkemeler arasında altlıküstlük ilişkinin kurularak bir hiyerarşi oluşturulması maksadıyla değil, hatalı karar verildiği şüphesinde olan kişiye, kararın bir üst mahkemede gözden geçirilmesini isteme olanağının sağlanması içindir.

Dereceli yargılamanın amacı bu şekilde olmakla birlikte, anayasal bir hak olup olmadığı konusu Türk Hukuku'nda uzun süredir tartışma konusudur. Konunun anayasal boyutu; hukuk devleti ilkesi, yüksek mahkemelerin Anayasa'da düzenlenme şekli, adil yargılanma hakkının kapsamı ile hak arama özgürlüğü, açısından ele alınmakta ve bu ilkelerle ilişkilendirilerek açıklanmaya çalışılmaktadır. ${ }^{16}$

Konunun, Uluslararası hukukta da çeşitli düzenlemelerle ele alındığı görülmektedir. Söz gelimi, Avrupa İnsan Hakları Sözleşmesi'nin 1984 tarihli ve 7 no.lu Ek Protokol'ün 2. maddesiyle ceza yargılamasında verilen mahkumiyet kararına karşı bireye, hükmün bir üst mahkeme tarafından incelenmesini isteme hakkı tanınmıştır. Söz konusu maddeyle, bireye yalnızca ceza davaları sonucunda verilen mahkumiyet kararına karşı üst mahkemeye başvurma hakkı tanınması gerektiği ifade edilmekte, aynı gerekliliğin hukuk

\footnotetext{
15 ÖZAY, (1991), s. 117; ÜSTÜNDAĞ, s. 816; BİLGE, s. 7.

16 AKIL, s. 225-226.
} 
davaları ve idari davalar için söz konusu olduğuna dair ise bir düzenleme yer almamaktadır. Bu sözleşmenin yanında, 1995 tarihli Avrupa Konseyi Bakanlar Komitesinin Hukuki ve Ticari Davalarda Kanun Yolu Sistemleri ve Usulleri İşlevinin Geliştirilmesi Hakkında 5 sayılı Tavsiye Kararı'nda, üst mahkemece inceleme usullerinin sadece ceza davaları için değil, aynı zamanda hukuk davaları ile ticari davalar için de kabul edilmesi gerektiği belirtilmiştir.

Adil yargılanma hakkının düzenlendiği Avrupa İnsan Hakları Sözleşmesi'nin 6. maddesinde ise, çok dereceli yargılamanın adil yargılanma hakkı için zorunlu bir unsur teşkil etmediğini; ancak, kanun yollarına başvurma hakkı taraf devletlerce tanınmışsa, bu durumda adil yargılanma için öngörülen esasların kanun yolları aşamasında da uygulanması gerektiği belirtilmiştir. ${ }^{17}$ Başka bir ifadeyle, AİHS'nin taraf devletleri çok dereceli yargılama usulünü kabul etmekle zorunlu tutmadığı; ancak, kanun yollarının düzenleme altına alınması halinde bu yollara başvuracak tarafların da her mahkemece ve derecede adil yargılanma hakkından yararlandırılması bakımından devletin yükümlülüğünün bulunduğu ifade edilmiştir. ${ }^{18}$

\section{B. Hukuk Devleti İlkesi Bakımından}

Türk Hukuku'nda dereceli yargılamanın anayasal bir hak olup olmadığ1 meselesi, öncelikle hukuk devleti ilkesinden yola çıkarak açıklanmalıdır. Başka bir ifadeyle, dereceli yargılamanın hukuk devleti olmanın bir gereği olup olmadığı hususu açıklığa kavuşturulmalıdır. Anayasamız, Cumhuriyetin nitelikleri başlığı altında yer alan 2. maddesinde, Türkiye Cumhuriyeti'nin bir hukuk devleti olduğunu hüküm altına almış; ancak, hukuk devleti ilkesinin esaslarının neler olduğunu belirtmemiştir. Bu ilkenin içinin doldurulması kimi zaman yargı organlarınca, kimi zaman doktrin tarafindan gerçekleştirilmiştir. Hukuk devleti ilkesi Danıştay'ın bir kararında şu şekilde ifade edilmiştir: "Hukuk devleti, insan hak ve özgürlüklerini ön planda tutan, bu haklart koruyucu, adaletli bir hukuk düzeni kuran ve bunu sürdürmekle kendisini yükümlü sayan, Anayasa'ya aykırı durum ve tutumlardan kaçınan, hukuku tüm Devlet organlarına egemen kilan, Anayasa ve hukukun üstün kurallarıyla kendini bağll sayan, yönetenlerin her türlü işlem ve eylemleri yargl denetimine tabi olan bir Devlettir." 19

17 YILDIRIM, (2000), s. 15.

18 GÖZÜBÜYÜK/GÖLCÜKLÜ, s. 312; TEZCAN/ERDEM/SANCAKDAR/ÖNOK, s. 231.

19 D. 11. D., E: 2012/6819, K: 2015/4223, T. 17.09.2015. Danıştay Dergisi, S. 141, 2016, s. 286. 
Hukuk devleti; vatandaşların hukuki güvenliğe sahip olduğu, devletin eylem ve işlemlerinin hukuka bağlı olduğu devlettir. ${ }^{20} \mathrm{O}$ halde bir devletin hukuk devleti olarak nitelendirilebilmesi için birtakım unsurları ihtiva etmesi gerekmektedir. Temel hak ve özgürlüklerin güvence altına alınması, kanuni idare ilkesinin geçerli olması, idarenin yargısal denetiminin mevcut olması, kuvvetler ayrılığı, kanunların Anayasa'ya uygunluğunun yargısal denetimi, suç ve cezaların şahsi olması, devletin mali sorumluluğu bulunduğunun kabul edilmesi ve demokrasinin yönetim biçimi olması hukuk devletinin unsurları olarak kabul edilmektedir. ${ }^{21}$

Hukuk devleti, devletin hukuka bağlı olduğu anlamına geliyorsa, yarg1 da hukuka bağlı olmak durumundadır. Nitekim yargı, devletin üç kuvvetinden birini oluşturmaktadır. Kaldı ki Anayasa'nın 11. maddesinde, yasama ve yürütmenin yanında yargının da Anayasa hükümleri ile bağlı olacağına ilişkin kural açıkça yer almaktadır. Yine Anayasa'nın 138. maddesinde hakimlerin, Anayasaya, kanuna ve hukuka uygun olarak karar verecekleri hükme bağlanmaktadır. Buradan çıkan sonuca göre yargının, devletin bir erki olarak keyfi davranma olasılığı söz konusu olamamakta, tüm işlem ve eylemlerinde hukuka bağlı kalması gerekmektedir. ${ }^{22}$ Ancak bunun aksinin gerçekleştiği bir durumda, yani yargının hukuk sınırlarının içerisinde hareket etmediğinin iddia edilmesi halinde, bu hususun kim ya da hangi merci tarafindan denetleneceği sorusu gündeme gelmektedir. Yargının bağımsız ve tarafsız bir konumda olması gereği, yasama ve yürütme tarafindan denetlenmesini imkansız kılacaktır. $\mathrm{Bu}$ nedenle yargısal kararların kim tarafından denetleneceği sorusuna verilecek yanıt şüphesiz ki, yine kendisi; başka bir ifadeyle, bir yarg1 merci eliyle yapılması gerektiği şeklinde olacaktır. Dolayısıyla, üst mahkemeler eliyle yargı mercileri kendi içerisinde bir denetim yapmaktadır. Kaldı ki mahkemelerin bir uyuşmazlık hakkında karar vermesi kamu gücünün yaşama geçirilme şekillerinden biri olduğundan, bunun üzerinde kanun yolu denetiminin varlığı, hukuk devleti ilkesinin bir gereğidir. ${ }^{23}$

Başka bir ifadeyle; kanunların Anayasa'ya uygunluk denetimi çerçevesinde yasama faaliyetinin yargı denetimine tabi tutulması; yine idarenin yargısal denetimi bağlamında, idarenin her türlü eylem ve işlemine

\footnotetext{
20 ÖZBUDUN, s. 125.

21 GİRITLİ/BILGEN/AKGÜNER/BERK, s. 78 vd.

22 GÖZLER, (2019) s. 83-84.

23 AKİL, s. 230; Y1ldırım, (2000), s. 19; YILDIRIM, (2008), 89.
} 
karş1 yarg1 yolunun açık olduğunun Anayasa'nın 125. maddesinde hükme bağlanması, hukuk devleti anlayışının bir tezahürüdür. Yasamanın ve idarenin hukuka aykırı davranabileceğinin ve dolayısıyla denetlenmelerinin gerektiği kabulü, yargının da aynı şekilde denetlenmesi gerektiğinin kabulü sonucunu doğurmaktadır. Yargıcın da hukuka aykırılık meydana getirecek kararlar verme ihtimalinin bulunması, kararların başka bir yargıç tarafından gözden geçirilmesini hukuk devletinin bir gereği olarak sayılmasını zorunlu kılmaktadır. Dolayısıyla, ilke olarak asıl varlık amacı yargının hukuka aykırılıklarını gidermek olan kanun yolu bu anlamıyla, bir uyuşmazlığı çözen yargının kararının hukuka uygun olup olmadığının kontrolü için yargılama usullerinde kabul edilmiştir.

Konu özellikle idari yargılama hukukunda özel bir öneme sahiptir. Şöyle ki, idari yargıda iptal davalarıyla amaçlanan, hukuka aykırı bir idari işlemin iptal edilerek idarenin hukuk sınırları içerisinde kalmasını sağlamaktır. Bu sayede hemen hemen tüm faaliyetlerinde temel hak ve hürriyetler ile yakın ilişki içinde bulunan idarenin, yapmış olduğu işlem ile birlikte aslında kendisi denetlenmektedir. Nitekim bu, hukuk devleti ilkesinin temel bir gereğidir. Başka bir ifadeyle, hukuk devleti ancak idarenin yargısal yolla denetimi sayesinde gerçekleşebilmekte, hukuk devletinin en somut şekilde görünümü bu yargısal yolla sağlanmaktadır. ${ }^{24} \mathrm{Bu}$ nedenle idari yargıda kanun yolları, mahkeme kararının üst yargı yerince incelenerek hakkın yerine getirilmesini sağlamaktan öte bir anlam taşımaktadır. Dolayısıyla ilk derece mahkemelerince verilen bir kararın doğru ve hakkaniyete uygun olup olmadığının denetlenmesi amacına hizmet eden kanun yolları, idari yargı için ayrıca önemli bir husus olarak karşımıza çıkmaktadır. ${ }^{25}$

Gerçekten hukuk devleti ilkesi ve geleneği, ilk derece mahkemelerince verilen kararların, kanunla düzenlenen denetim yargılaması çerçevesinde incelemeye açık olmasını gerektirir. Mahkemeler tarafından verilen nihai kararların hukuka aykırı olarak verilmesi durumunda, söz konusu hukuka aykırılık nedeniyle kişilerin haklarının ya da hukuken korunan yararlarının zarar görmesini engellemek, ihlali sona erdirmek için verilen kararın bir kez daha incelenmesi imkanını kişilere tanımak hukuk devleti ilkesinin bir gereğidir. ${ }^{26}$

\footnotetext{
24 ÖZAY, (2017), s. 16.

25 AYDINOĞLU, s. 392.

26 ÖZTÜRK., s. 537.
} 


\section{Yüksek Mahkemelerin Anayasal Konumlarının Gerekleri Bakımından}

Türk Anayasası'nda idari yargılama hukuku açısından, mahkeme kararlarının bir üst yargı merci tarafindan kontrol edilmesi gerektiğine, başka bir ifadeyle dereceli yargılamanın anayasal hak olduğuna ilişkin düzenleme, Anayasa'nın 155. maddesinde yer almaktadır. Söz konusu madde, Anayasa'da yüksek mahkeme olarak ifade edilen Danıştay'a ilişkindir. Anayasa'da yüksek mahkemelerin düzenlendiği hükümlerden dereceli yargılamanın anayasal bir hak olduğu yargısına ulaşmak mümkün görünmektedir. ${ }^{27}$ Anayasa 155. maddesinde, Danıştay'ın işlevini şu şekilde hüküm altına almıştır: 'Danıştay, idari mahkemelerce verilen ve kanunun başka bir idari yargı merciine bırakmadiğı karar ve hükümlerin son inceleme merciidir. Kanunla gösterilen belli davalara da ilk ve son derece mahkemesi olarak bakar."

Söz konusu hüküm, mahkeme kararlarının bir üst mahkeme tarafından kontrol edilmesi zorunluluğunu açıkça düzenlemektedir. Hükümlerde yer alan "karar ve hükümlerin son inceleme mercii" ifadesi, dereceli yargılamanın bulunması gerektiğini ve bunun anayasal bir hak olduğunu ortaya koymaktadır. Ayrıca "kanunun başka bir idari yargı merciine bırakmadı̆̆ı" ifadesiyle, kanun koyucunun ilk derece mahkemesi kararlarının incelenmesi görevini, Danıştay dışında başka bir üst mahkemeye bırakabileceği anlatılmak istenmektedir. ${ }^{28}$ Nitekim Türk Hukuk Sistemi'nde, Danıştay yanında; bölge idare mahkemeleri de kanun yolu incelemesinde görevli merciler olarak karşımıza çıkmaktadırlar.

$\mathrm{Bu}$ düzenlemeden çıkan sonuca göre, ilk derece mahkemesi kararlarının ya başka bir üst mahkemede ya da Danıştay' da kontrol edilmesi gerekmektedir. $\mathrm{Bu}$, Anayasa'nın gereğidir. Başka bir ifadeyle, dereceli yargılamanın anayasal temellerinden biri de bahsi geçen hükümlerdir. Her ne kadar Anayasa'nın 142. maddesinde mahkemelerin kuruluş, görev ve yetkilerinin, işleyişlerinin ve yargılama usullerinin kanunla düzenleneceği; başka bir ifadeyle bu konuda kanun koyucunun takdir yetkisine sahip olduğu düzenleme altına alınmış olsa da kanun koyucunun yapacak olduğu düzenlemelerde, Anayasa'nın 155. maddesini tamamıyla göz ardı etmemesi gerekir. ${ }^{29} \mathrm{Bu}$ bakımdan kanun koyucunun, ilk derece mahkemeleri tarafindan verilen tüm kararlara

\footnotetext{
27 ALANGOYA, (2004), s. 30.

28 AKKAYA, s. 45.

29 AKIL, s. 231.
}

Ankara Hac1 Bayram Veli Üniversitesi Hukuk Fakültesi Dergisi C. XXIV, Y. 2020, Sa. 3431 
karşı kanun yolunun kapalı olacağı şeklinde yapacak olduğu düzenlemeler Anayasa'ya aykırılık teşkil edecektir. ${ }^{30} \mathrm{Bu}$ şekildeki bir düzenleme, Yüksek Mahkemenin konumuna Anayasal bir koruma getiren 155. madde hükmünün içinin boş kalmasına; başka bir ifadeyle, Anayasa'nın 155. maddesinde hüküm altına alınan Yüksek Mahkeme'nin ya da kanun yolu incelemesinde kendisine kanunla görev verilen başka bir yargı merciinin varlığının bir anlamının kalmamasına neden olacaktır. Ancak belirtilmelidir ki; mahkeme kararlarının hukuka uygunluğunun bir üst mahkeme tarafından denetlenmesi anayasal gereklilik olmakla birlikte, Anayasamızda kanun yolunun kaç dereceli olması gerektiği konusunda herhangi bir hüküm yer almamaktadır. ${ }^{31}$

\section{Hak Arama Hürriyeti ile Adil Yargılanma Hakkı Bakımından}

Dereceli yargılamanın anayasal bir gereklilik olduğu konusunda dayanak alınabilecek diğer bir düzenleme, Anayasa'nın 36. maddesinde yer alan hak arama özgürlüğüdür. Hükme göre, 'herkes, meşru vasita ve yollardan faydalanmak suretiyle yargı mercileri önünde davacı veya davalı olarak iddia ve savunma ile adil yargllanma hakkına sahiptir." Hak arama özgürlüğü; Anayasa, uluslararası metinler ve kanunlarla kişilere tanınan hak ve özgürlüklerin ihlal edilmesi durumunda, bu hakların gerçekleştirilebilmesi ve korunabilmesi için etkili bir yargısal denetim sunulmasını isteme imkanının tanınmasıdır. ${ }^{32}$ Bu etkili yargısal denetimin kapsamına kanun yolunun da girip girmeyeceğinin tespiti aynı zamanda, kanun yoluna başvurma hakkının hak arama özgürlüğünün bir parçası olup olmadığının tespitini yapmak demektir.

30 AKİL, s. 232. Ancak Anayasa Mahkemesi 2001 tarihinde, ifade ettiğimiz husustan farklı bir karar vermiştir. Karar, 4077 sayılı Tüketicinin Korunması Hakkında Kanun'un bu Kanun uyarınca verilen idari para cezalarına karşı yetkili idare mahkemesine yapılan itiraz neticesinde verilen kararların kesin olmasının Anayasa'nın 155. maddesine aykırı bir yönü olmadığına ilişkindir. Söz konusu kararda mahkeme şu değerlendirmeleri yapmıştır: "Ayrıca, Anayasa'da tüm mahkeme kararlarının temyiz edileceğine ilişkin bir hükme yer verilmemiştir. Öğretide bu yönde bir zorunluluk olduğu kabul edilmemistir. Anayasa Mahkemesi'nin konuya ilişkin kararları da, kamu yararı gerektirdiğinde ve hukuk devleti kavramı ile bağdaşmayacak sonuçlara yol açma olasılığının bulunmadiğı durumlarda kimi kararlar için kanun yollarına başvurmanın önlenebileceği yönündedir. Yargı denetiminde sonsuzluk olamayacağından, bunun bir yerde kesilmesi gerekir. Anayasanın 13. maddesine göre temel hak ve özgürlükler kamu yararı ile sinırlanabilir. İtiraz konusu kuralla, kanun yoluna başvurulmasına olanak vermeyecek biçimde hak arama özgürlügüne kamu yararı amacı ile getirilen sinırlamada, demokratik toplum düzeninin gereklerine aykırllı bulunmamaktadır. Anayasanın Danıştayl, idare mahkemelerince verilen kararların son inceleme mercii olarak tanımlayan 155. maddesinde, tüm kararların mutlak olarak Danıștay incelemesinden geçirileceği konusundan bir kural yer almamaktadır.” AYM, E: 2001/232, K: 2001/89, T. 23.05.2001, R.G. 19.01.2002/24645. ALANGOYA, (2004), s. 27.

31 ÖZEKES, s. 2153

32 ATALAY, s. 449.

432 Ankara Hacı Bayram Veli Üniversitesi Hukuk Fakültesi Dergisi C. XXIV, Y. 2020, Sa. 3 
Hak arama özgürlüğ̈̈nün temelinde, hakları ihlal edilen kişilerin, ihlalin sonlandırılması ve ihlalin yarattığ amacıyla yargı makamlarına başvurabilmesi ve bu hakkın kullanılabileceği başvuru mekanizmalarının kişilere sunulması amacı yatmaktadır. ${ }^{33}$ Kanun yolunun amaçlarından biri ve belki de en önemlisi, yarg1 yerlerince verilen kararlardaki hukuka aykırılıkların incelenmesi suretiyle somut olaylarda adaletin gerçekleşmesinin sağlanmasıdır. Bu doğrultuda kanun yolu incelemesi neticesinde verilen yargı kararları tarafları tatmin eder biçimde, tarafların aralarındaki uyuşmazlığı ortadan kaldıracağından adalet anlayışı içinde haklar dağıtılmış olacaktır. Bu husus ise, yukarıda işlevinden bahsedildiği üzere hak arama özgürlüğünün gereği olarak ortaya çıkacaktır. Dolayısıyla kanun yollarına başvuru hakkının, hak arama özgürlüğünün kapsamı içerisinde değerlendirilmesi gerekmektedir. ${ }^{34}$ Kaldı ki; hak arama özgürlüğ̈̈, ihlal edilen hakkın temini için yargı yerlerine başvurmak olduğuna göre, söz konusu ihlal yarg1 yerleri tarafından da yapılmış olabileceğinden, ilgili tarafın hakkının etkin bir şekilde korunabilmesi için kanun yoluna başvuru hakkının hak arama özgürlüğü içinde değerlendirilmesi gerekir.

Anayasa'nın hak arama özgürlüğünü düzenleyen 36. maddesinde 2001 yılında 4709 sayılı Kanunla değişiklik yapılmış, fikraya adil yargılanma hakkı da eklenmiştir. Başka bir ifadeyle 36. maddede hak arama özgürlüğü ile birlikte adil yargılanma hakkı da anayasal güvenceye kavuşturulmuştur. Adil yargılanma hakkı sadece Anayasamızda değil, iç hukukumuzda uygulanma etkisine sahip olan Avrupa İnsan Hakları Sözleşmesi'nin 6. maddesinde de yer almaktadır. Anayasamızda ve Sözleşmede adil yargılanma hakkının tanımına ilişkin bir düzenleme bulunmamaktaysa da, adil yargılanma hakkının kapsamına dahil olan unsurların neler olduğunun belirlemesi Sözleşmede yapılmıştır. Buna göre adil yargılanma hakkının unsurları; kanuni, bağımsız ve tarafsız bir mahkemeye başvurma ve bu mahkeme önünde yargılanma, makul süre içinde yargılanma, aleni olarak yargılanma, hakkaniyete uygun olarak yargılanma şeklinde belirtilmektedir. ${ }^{35}$

Adil yargılanma hakkının unsurlarından olan mahkemeye başvuru hakkının, kanun yollarına başvuru açısından da geçerli olup olmadığı hususu ele alınması gereken bir diğer konudur. Avrupa İnsan Hakları Sözleşmesi’nin

\footnotetext{
33 GÜL/BİRTEK, s. 6.

34 YILMAZ, (1988), s. 142.

35 TANRIVER, s. 213.
} 
adil yargılanma hakkı başlıklı 6 . maddesine bakıldığında, istinaf ya da temyiz gibi bir üst mahkemeye başvuru hakkının adil yargılanmanın zorunlu bir güvencesi olmadığ1 görülmektedir. Bununla birlikte iç hukukta böyle bir yol öngörülmüşse üst mahkeme aşamasında adil yargılanmanın gereklerine uyulmalıdır. Avrupa İnsan Hakları Mahkemesi, iç hukukta temyiz ya da istinaf gibi bir kanun yolu genel olarak kişilere tanınmış; fakat, bazı dava türleri için bu yol kapatılmış ise, bu durumda adil yargılanma hakkı kapsamında mahkemeye başvuru hakkının ve bunun yanında ayrımcılık yasağının ihlal edildiğini kabul etmektedir. ${ }^{36}$

Mahkemeye başvurma hakkı kişilere, iddialarını bir yargı merciine sunabilmesi imkanının tanınması ve kişilerin bu imkanın kendilerine sağlanmasını isteme anlamına gelmektedir. ${ }^{37}$ Başka bir ifadeyle, bir kimsenin hakkını etkili biçimde elde edebileceği yargısal bir kuruluşa ulaşmasını ifade etmektedir. ${ }^{38}$ Buna göre mahkemeye başvurma hakkı bir kimsenin hakkını elde etmesi için kendisine usuli imkanların tanınmasını gerektirdiğinden, bu kapsamın içine kanun yoluna başvurma hakkı da girmektedir. Bu nedenle, ilk derece mahkemesindeki yargılamada hakkı ihlal edilen kişi açısından dereceli yargılama aynı zamanda adil yargılanma hakkının da bir gereğidir.

Anayasa Mahkemesi 2014 tarihinde verdiği bir kararında, kanun yoluna başvurma hakkının hak arama hürriyeti ve adil yargılanma hakkı kapsamı içinde yer aldığını ifade etmiştir. Yüksek Mahkeme söz konusu kararında şu değerlendirmelere yer vermiştir: "Anayasa'nın hak arama hürriyetini düzenleyen 36. maddesinin birinci fikrasinda, herkes meşru vasita ve yollardan faydalanmak suretiyle yargı mercileri önünde davacı ve davalı olarak iddia ve savunma ile adil yargllanma hakkına sahiptir. hükmüne yer verilmiştir. Maddeyle güvence altına alınan hak arama özgürlügü ve adil yargılanma hakkl, kendisi bir temel hak niteliği taşımasının yanında, diğer temel hak ve özgürlüklerden gereken şekilde yararlanılmasını ve bunların korunmasinı sağlayan en etkili güvencelerden biridir. Anayasa Mahkemesinin daha önceki kimi kararlarında da belirtildiği üzere, kanun yoluna başvurma hakkı da, hak arama hürriyeti ve adil yargılanma hakkı kapsamindadır. "39

Anayasa Mahkemesinin yine kanun yoluna başvuru hakkının adil yargılanma hakkı kapsamında olduğuna ilişkin verdiği bir kararında da şu

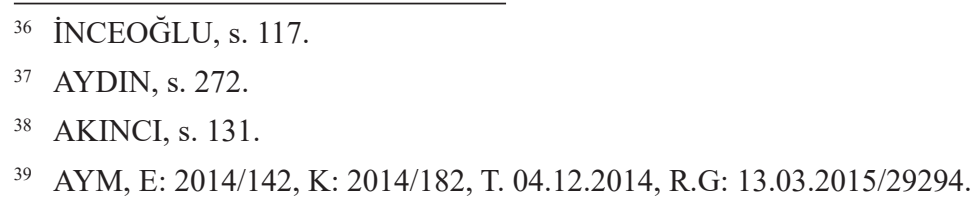


ifadelere yer vermiştir: "'...Kanun yolu, bir yargl yeri tarafindan verilen ve hukuka aykırı olduğu ileri sürülen bir kararın, kural olarak başka bir yargı yeri tarafindan incelenmesini sağlayan hukuki yoldur. Kanun yolunun amacl, yargı yerleri tarafindan verilen kararların, kural olarak başka bir yargı yeri tarafindan denetlenmesine imkan tanımak suretiyle daha güvenceli bir yargl hizmeti sunmaktır. Kanun yoluna başvuru hakkı, adil yargılanma hakkının kapsamı içindedir". ${ }^{40}$

Nihayetinde söyleyebiliriz ki, dereceli yargılama hukuk devleti ilkesinin bir gereğidir. Bu noktada dereceli yargılamanın Türk Hukuku açısından anayasal temelleri bulunmakta olup, dolayısıyla kanun yoluna başvurmak anayasal bir haktır. Ayrıca kanun yoluna başvurma hakkı; Yüksek Mahkemelerin Anayasa'da düzenlenişi itibariyle, hak arama özgürlüğü ve adil yargılanma hakkının bir gereği olarak da Anayasa ile tümüyle uyumludur.

\section{KANUN YOLLARINA BAŞVURU HAKKININ NE ÖLÇÜDE SINIRLANDIRILABİLECEĞİ MESELESİ}

Kanun yoluna başvuru hakkının anayasal bir hak olduğunun kabulü, bu hakkın nasıl ve ne ölçüde sınırlandırılabileceği hususunun değerlendirilmesini gerektirmektedir. Temel hak ve hürriyetlerin sınırlanmasına ilişkin esaslar, Anayasa'nın 13. maddesinde düzenlenmiştir. Buna göre; "temel hak ve hürriyetler, özlerine dokunulmaksızın yalnızca Anayasanın ilgili maddelerinde belirtilen sebeplere bağll olarak ve ancak kanunla sinirlanabilir. Bu sinırlamalar, Anayasanın sözüne ve ruhuna, demokratik toplum düzeninin ve laik Cumhuriyetin gereklerine ve ölçülülük ilkesine aykırı olamaz"

Anayasa'da 2001 yılında 4709 sayılı Kanun ile yapılan değişiklik neticesinde, bir temel hak ve hürriyetin sınırlandırılabilmesi için, o hak ve hürriyetin düzenlendiği maddede belirtilen sebeplerin mevcudiyeti gerekir. Başka bir ifadeyle, kamu yararı gibi genel birtakım sebeplere bağlı olarak hak ve hürriyetlerin sınırlandırılması mümkün değildir. O halde öncelikle, kanun yolunun anayasal temelini oluşturan Anayasa'nın hak arama hürriyeti başlıklı 36. maddesinde, bu hakka ilişkin sınırlama sebeplerinin öngörülüp öngörülmediğine bakılmalıdır. Ancak, hak arama özgürlüğünün düzenlendiği maddede söz konusu hak bakımından herhangi bir sinırlama sebebine yer verilmediği görülmektedir. $\mathrm{Bu}$ durum karşısında kanun yoluna başvuru hakkına hiçbir şekilde sınırlama getirilmesi mümkün değil midir?

40 AYM, E: 2014/164, K: 2015/12, T. 14.01.2015, R.G. 22.05.2015/29263.

Ankara Hacı Bayram Veli Üniversitesi Hukuk Fakültesi Dergisi C. XXIV, Y. 2020, Sa. 3435 
Bahsi geçen husus doktrinde tartışmalıdır. Kimi yazarlar, maddede belirtilenlerin dışında başka bir sınırlama sebebine dayanılarak hakların sınırlandırılmasının mümkün olmadığını; bu noktada, maddede herhangi bir sınırlama sebebi öngörülmemişse sınırlandırmanın söz konusu olamayacağını ifade etmektedir. ${ }^{41}$ Başka bir görüş, Anayasa'da bir temel hak ve özgürlüğü düzenleyen maddede herhangi bir özel sinırlama sebebi öngörülmeyen hallerde dahi o hak ya da özgürlüğün "pratik uyuşum ilkesi" gereğince sinırlandırılabilmesinin mümkün olduğunu belirtmektedir. ${ }^{42}$ Söz konusu görüşün dayandırıldığı ilke uyarınca, ' 'bir temel hakkın başka bir temel hak ya da anayasanın koruduğu başka bir hukuki değerle çatışması halinde, öyle bir çözüm bulunmalıdır ki, gerek temel hak gerekse anayasanın koruduğu hukuki değer varlık ve etkilerini optimal düzeyde korusun.". ${ }^{43}$ Buna göre hak arama özgürlügünün hiçbir şekilde sinırlanamayacağı kabul edilirse, Anayasa'nın koruduğu başka bir hukuki değer etkisiz hale gelebilir. Söz gelimi, Anayasa'nın 141. maddesi davaların en az giderle ve mümkün olan süratle sonuçlandırılmasının yargının görevi olduğunu ifade etmiştir. $\mathrm{Bu}$ bakımdan hak arama özgürlügünün hiçbir şekilde sınırlandırılmasının mümkün olmadığından bahisle tüm yargı kararlarına karşı kanun yoluna başvuru hakkının tanınması, davaların süratle çözüme kavuşturulmasının etkisiz hale gelmesine yol açabilmektedir. Başka bir ifadeyle, hak arama özgürlüğü kapsamında tüm yargı kararlarına karşı kanun yolunu açık tutmak, yargının iş yapabilirliği hususunda engel teşkil edebilmektedir. Dolayısıyla, yargının iş yapamaz duruma gelmesi halinde; yargının fonksiyon yapabilirliğinin muhafazası için belirli ölçütlere uymak suretiyle, hak arama özgürlüğünde sınırlandırma yapılabilmesi mümkündür. ${ }^{44}$

\footnotetext{
41 Bahsi geçen değerlendirme için bkz: GÖZLER, (2001), s. 53-67.

42 Anayasa Mahkemesi’nin yakın tarihli kararlarında da, özel sınırlama nedeni öngörülmediği halde hak arama özgürlüğünün sınırlandırılabileceği ifade edilmektedir: 'Anayasa'nın 36. maddesinde, hak arama özgürlügü güvence altına alınmıştır. Maddede, hak arama özgürlüğ̈̈ için herhangi bir sinırlama nedeni öngörülmemiş olmakla birlikte, bunun hiçbir şekilde sinırlandırılması mümkün olmayan mutlak bir hak olduğu söylenemez. Özel sinırlama nedeni öngörülmemiş hakların da hakkın doğasından kaynaklanan bazı sinırları bulunduğu kabul edilmektedir. Ayrıca hakkı düzenleyen maddede herhangi bir sinırlama nedenine yer verilmemiş olsa da, Anayasa'nın başka maddelerinde yer alan kurallara dayanarak bu hakların sinırlandırılması mümkün olabilir." AYM, E: 2015/96, K: 2016/9, T. 10.02.2016, R.G. 23.02.2016/29633. Benzer bir karar için bkz: AYM, E: 2013/148, K: 2014/62, T. 27.03.2014, R.G. 23.05.2014/29008.

43 SAĞLAM, s. 40.

44 ALANGOYA, (2004), s. 36.
} 
Söz konusu görüş doğrultusunda, kanun yoluna başvurma hakkının sınırlandırılabilmesi kabul edilse dahi, bu sınırlamaların ölçülülük ilkesine uygun olmak suretiyle yapılması gerekmektedir. Ölçülülük, başvurulan aracın sınırlama amacını gerçekleştirmeye elverişli olması, bu amaç açısından gerekli bulunması ve araç ile amacın ölçüsüz bir oran içinde bulunmamasını ifade etmektedir. ${ }^{45} \mathrm{Bu}$ bakımdan, kanun koyucuların kanun yoluna başvuru hakkına getirecek oldukları sınırlamalarda serbestiye sahip olmadıkları aşikardır. Dolayısıyla, sınırlandırma keyfi olamaz. Sınırlandırmanın da sınırı olup; bu açıdan, meşru bir amacın bulunması ve hakkın özüne dokunulmaması gerekir. Söz konusu sınırlamalardaki ölçü bakımından; kamu yararı, işin esasına uygunluk, yargının görev yapabilmesine imkan verme kriterleri esas alınmalıdır. ${ }^{46}$

Türk Hukuku'nda ise, kanun yoluna başvuru hakkının genel olarak meblağ sınırı getirilmek suretiyle sinırlandırıldığı görülmektedir. $\mathrm{Bu}$ bakımdan uyuşmazlığın parasal değeri esas alınarak yapılan sınırlamada, hakkını alamadığı kanaatinde olan kişilerin dikkate alınması, kaybedilen ekonomik değerin kolayca vazgeçilebilir nitelikte olması ve bu şekilde amacın hissedilebilir bir şekilde gerçekleşebilmesi şartlarının varlığı gerekmektedir. ${ }^{47}$ O halde yargının iş yapabilirliğinin sağlanması amacıyla kanun yoluna başvuru hakkına sınırlamalar getirilmesi mümkündür. Buradaki sorun, getirilecek meblağın miktarının tespitinin doğru bir şekilde yapılıp yapılmadığıdır. Şöyle ki, sırf yargının iş yükünün hafifletilmesi pahasına, ekonomik sebeplerden ötürü toplumun büyük bir çoğunluğunun kanun yoluna başvuramayacağ 1 nicelikteki bir parasal değer, sınırlandırmanın ölçüsüz olduğu anlamına gelecektir. Bu, aynı zamanda Anayasa'da hüküm altına alınan sosyal devlet ilkesine de aykırılık teşkil edecektir. ${ }^{48} \mathrm{Bu}$ bakımdan kanun yoluna başvuruda ağır parasal sınırlar getirmek, ekonomik açıdan güçsüz olan kişileri, adillik konusunda şüpheye düşmeleri halinde haklarını dava yoluyla aramaktan caydırabilecek; bu husus ise, sosyal devlet ilkesinin gereklerine aykırı olma sonucunu doğuracaktır. Nitekim sosyal devlet kavramının anlamlandırılması, kişinin temel hak ve hürriyetlerini, sosyal hukuk devleti ve adalet ilkeleriyle bağdaşmayacak suretle sınırlayan siyasal, ekonomik ve sosyal engelleri kaldırmaya, kişinin maddi ve manevi varlığının gelişmesi için gerekli

\footnotetext{
45 SAĞLAM, s. 114.

46 ALANGOYA, (2004), s. 39.

47 ÖKÇESIZ, s. 77-78.

48 ALANGOYA, (1981), s. 4.
}

Ankara Hac1 Bayram Veli Üniversitesi Hukuk Fakültesi Dergisi C. XXIV, Y. 2020, Sa. 3437 
şartları hazırlamaya çalışmak ödevinin yerine getirilmesinin sağlanması ile mümkündür. ${ }^{49}$

Anayasa Mahkemesi'nin 1986 tarihli bir kararında da yukarıda ifade edilen ilkeler açısından, ilk derece mahkemesi kararlarına karşı kanun yollarının kapatılmasının ne şekilde mümkün olabileceği tartışılmıştır. Söz konusu olayda, HUMK'un 427. maddesi gereğince belli bir meblağ 1 geçmeyen taşınır mal ve alacak davalarına ilişkin ilk derece mahkemelerince verilen kararların kesin olacağı; başka bir ifadeyle, bu kararlara karşı kanun yollarına başvurunun mümkün olmamasının, Anayasa'nın hukuk devleti, eşitlik, sosyal adalet ilkelerine ve hak arama hürriyetine aykırılık oluşturduğu iddiası bulunmaktadır. Anayasa Mahkemesi söz konusu hükmün Anayasa'ya aykırı olmadığını; kamu yararı gerektirdiğinde bazı hükümler için kanun yollarına başvurmanın önlenmesinin mümkün olduğunu, kanun koyucunun Anayasa'nın 142. maddesi gereğince yargılama usullerini belirleme konusunda takdir yetkisi bulunduğunu, itiraz konusu kuralla davaların süratlendirilmesi ve Yargıtay'ın iş yükünün bir ölçüde azaltılmasının amaçlandığını, diğer temel hak ve hürriyetler gibi hak arama özgürlügünün de kamu yararı dikkate alınarak sinırlandırılabileceğini, itiraz konusu kuralda varlıklı kimseler ile ekonomik bakımdan güçsüz olan kimseler bakımından bir ayrım yapılmadığını ve herkesin aynı hükme tabi tutulduğunu; bu bakımdan eşitlik ilkesine ve sosyal devlet ilkesine aykırı bir yönünün bulunmadığını, mahkeme kararlarının tümünün kanun yollarına tabi olma zorunluluğunu doğuran bir anayasal hüküm olmadığını, keza her mahkeme kararının kanun yoluna tabi olması zorunluluğunun hakimlere güvensizliğin bir işareti olabileceği ve yarg1 denetiminde sonsuzluğun olamayacağı bir yerde kesinleşmesi gerektiğini bu nedenle söz konusu hükmün bu gerekçelerle Anayasa'ya aykırı olmadığını ifade etmiştir. ${ }^{50}$

49 ÖZBUDUN, s. 139.

50 AYM, E: 1985/23, K: 1986/2, T. 20.01.1986, R.G: 16.04.1986/19080. Benzer kararlar için bkz: AYM, E: 2004/43, K: 2008/56, T. 07.02.2008, R.G. 19.03.2008/26821; E: 2006/65, K: 2009/114, T. 23.07.2009, R.G. 07.10.2009/27369; E: 2014/146, K: 2015/31, T. 19.03.2015, R.G. 13.06.2015/29385. Anayasa Mahkemesi'nin ilk derece mahkemelerince verilen baz1 hükümlere karşı kanun yollarının kapalı olması hususundaki iptal/itiraz başvurularına ilişkin verdiği kararların gerekçeleri genel olarak benzerdir. Yüksek Mahkeme, kanun koyucunun Anayasa'nın 142. maddesi gereğince yargilama usullerini düzenleme konusunda takdir yetkisi bulunduğunu, Anayasa'da kanun yoluna başvuru hakkı konusunda zorunluluk getiren bir düzenleme bulunmadığını, mahkemelerin iş yükünün bir ölçüde azaltılmasının amaçlandığını, getirilen sınırlamaların kamu yararına yönelik olduğunu ve dolayısıyla mahkemelerce verilen bazı hükümlere karşı kanun yollarının kapalı olmasının Anayasa'ya aykııı bir yönünün olmadığını ifade etmektedir. 
Anayasa Mahkemesi söz konusu kararında kamu yararının gerektirdiği durumlarda, yüksek mahkemelerin iş yükünün hafifletilmesi amaciyla, hak arama özgürlüğü bakımından kanun yollarına başvuru hakkına sınırlamalar getirilebileceğini ifade etmekteyse de; mahkemelerin iş yüklerinin ne pahasına olursa olsun hafifletilmesi meşru görülmemelidir. Burada kişilerin hak arama özgürlügünden kaynaklanan menfaatleri ile yüksek mahkemelerin iş yüklerinin hafifletilmesinin sağlayacağı kamu menfaati arasında dengenin kurulması önemlidir. ${ }^{51}$ Esasen bu dengenin kurulabilmesi, hak arama özgürlüğü bağlamında kanun yollarına başvuru hakkına getirilecek sınırlamaların, ölçülülük ilkesi içerisinde olabilmesine olanak sağlaması bakımından da son derece önem arz etmektedir.

Kanun yoluna başvuru hakkının somut anayasal dayanağı olan hak arama özgürlüğünün sınırlanmasında kıstas alınması gereken bir diğer husus, hakkın özüne dokunma yasağıdır. Temel hak ve hürriyetlerin özüne dokunma yasağına göre, yapılacak sınırlamalar bu temel hak ve hürriyeti kullanma imkanını tamamen ortadan kaldırmamalı; başka bir ifadeyle, hakkı tümüyle kullanılamaz hale getirmemelidir. ${ }^{52} \mathrm{Bu}$ bakımdan mahkeme kararlarının tümüne karşı kanun yoluna başvuru hakkı tanınması, kararların kontrolünü olumsuz yönde etkilediği ve hak arama özgürlügünün uygulanmasinda olumsuz durumlar yaratması ihtimalinin hukuk devletinin temel koşullarından olan, yargının işlevini yerine getirmesi ilkesini zarara uğratabileceği durumlarda sinırlamaya gidilmesi mümkündür. Böyle bir durum, hak arama hürriyetini ortadan kaldırmak anlamına gelmeyecektir. Zira kişilerin ilk derece mahkemeleri önünde hak arama hürriyetlerinin varlığı devam etmektedir. ${ }^{53}$ Dolayısıyla, hak arama özgürlüğünün özü ortadan kalkmış olmamaktadır. Kanun yollarına başvurunun meblağ sınırları gereğince mümkün olmaması hallerinde hakkın sınırlanması söz konusu ise de özüne dokunulmamaktadır. ${ }^{54}$

Yargılama usullerine göre kanun yollarının kapalı olduğu mahkeme kararlarının sınırlama ölçütleri bakımından değerlendirilmesi, pozitifhukuktaki düzenlemelerin hukuka uygunluğunun tespitinin ortaya konulabilmesi açısından önemlidir. Yargılama usulüne ilişkin çeşitli kanunlarda, ilk derece mahkemesinde kesinleşen kararlar düzenlenmiştir. Bu kararlar verildikleri

\footnotetext{
51 ÖKÇESIZ, s. 75.

52 GÖZLER, (2019), s. 130.

53 ALANGOYA, (2004), s. 36.

54 KÖKÜSARI, s. 173-174.
} 
an kesin hüküm halini almış olan kararlardır. Başka bir ifadeyle, bunlar için kanun yoluna başvuru yolu kapatılmıştır. Söz konusu düzenlemeler hem İdari Yargilama Usulü Kanunu'nda hem de Hukuk Muhakemeleri Kanunu ile Ceza Muhakemesi Kanunu'nda yer almaktadır.

İdari Yargilama Usulü Kanunu'nun 45. maddesinde 2014 yılında, 6545 sayılı Kanun ile yapılan değişiklik neticesinde itiraz kanun yolu kaldırılarak, istinaf kanun yolu ihdas edilmiştir. İstinafa tabi ilk derece mahkemesi kararları sayma suretiyle belirtilmiş değildir. Kural olarak ilk derece mahkemelerince verilen kararlar istinaf kanun yoluna tabi tutulmuştur. $\mathrm{Bu}$ nedenle, idari yargılama hukukunda değişiklik sonrasında istinaf, genel kanun yolu olma özelliğine sahip olmuştur. ${ }^{55}$ Ancak maddede, konusu yedi bin Türk Lirasını geçmeyen ${ }^{56}$ vergi davaları, tam yargı davaları ve idari işlemlere karşı açılan iptal davaları hakkında idare ve vergi mahkemelerince verilen kararların kesin olduğu hükme bağlanmıştır. Bu kararlar, ilk derece mahkemelerinde verildikleri an kesin olup kanun yoluna başvuru konusu yapılamamaktadır.

Kanun yoluna başvuru, anayasal bir haktır. $\mathrm{Bu}$ hakkın temel dayanaklarından biri ise, Anayasa'nın 36. maddesinde düzenleme altına alınan hak arama hürriyetidir. Temel hak ve hürriyetlerin sinırlanması ise, Anayasa'nın 13. maddesinde belli esaslara tabi tutulmuştur. Buna göre, sınırlamaların yapılması Anayasa'nın ilgili maddelerinde belirtilen sebeplere bağlı olarak ancak kanun ile mümkündür. Ancak söz konusu sınırlamanın sınırları vardır. Bu sınırlar, hakkın özüne dokunmama ve ölçülülük ilkesine uygunluktur. Konuya idari yargılama hukuku açısından bakılacak olursa, ilk derece mahkemelerince verilen kararların kanun yoluna tabi olmasının şartı yedi bin Türk Liralık parasal sınırın aşılmış olmasıdır. Aksi halde tarafın, kanun yoluna başvurma hakkı bulunmamaktadır. Kanun yoluna başvurulabilmesi için böyle bir sınırın getirilmesi, hak arama özgürlüğü bakımından ne kadar ölçülü bir sınırlamadır? Şüphesiz ki, böyle bir sınırın getirilmemesi ve değeri her ne olursa olsun ilk derece mahkemesinin her türlü kararına karşı kanun yoluna başvuru hakkının tanınması üst derece mahkemelerinin iş yükünü çok arttırabilirdi. Fakat burada asıl önemli olan husus, getirilen meblağ sınırının

55 AKYILMAZ/SEZGINER/KAYA, s. 851.

562020 y1lı için geçerli olan bu parasal tutar, 213 sayı1ı Vergi Usul Kanununun mükerrer 298'inci maddesi hükümleri uyarınca Hazine ve Maliye Bakanlığınca her yıl tespit ve ilan edilen yeniden değerleme oranında artıılması suretiyle uygulanır. Ancak bu şekilde belirlenen sınırların bin Türk lirasını aşmayan kısımları dikkate alınmaz. (IYUK Ek Madde 1). 
çok yüksek olmaması gereğidir. ${ }^{57} \mathrm{Bu}$ açıdan üst derece mahkemelerinin iş yükünü azaltmak bakımından, kesinlik sınırının çok yüksek tutulması, gerçekleştirilmesi istenen yararla, kişilerin haklarının götürülmesi sonucunu doğurabilmektedir. İdari yargılama hukuku açısından getirilen yedi bin Türk Liralık meblağ sınırının tespitinde ise; hangi kıstasların kullanıldığı, neden bu değerin belirlendiği noktasında kanun gerekçesinde de herhangi bir açıklama mevcut değildir. ${ }^{58} \mathrm{Bu}$ meblağ ile hak arama özgürlüğüne getirilen sınırlamaların ölçülü olabilmesi için ülkede, tespit edilebildiği kadarıyla, en alt gelir grubunu oluşturan kesim düşünülerek en azından asgari ücret düzeyinden daha düşük bir sınırlamanın getirilmesi uygun olacaktır. ${ }^{59} \mathrm{Bu}$ sayede hak arama özgürlüğünün ölçülülük ilkesine uygun sınırlandığından bahsetmek mümkün hale gelebilecektir.

\section{SONUÇ}

Kanun yollarının, fonksiyonları bakımından birçok işlevi yerine getirdiğini söylemek mümkündür. Buna göre kanun yollarının varlığı, kendisi hakkında hukuka aykırı karar verildiği kanaatinde olan tarafin tatmin edilmesi yanında, uyuşmazlığın taraflarının ve giderek tüm toplumun adalet duygusunun güçlendirilmesine katkı sağlamaktadır. ${ }^{60} \mathrm{Bu}$ bakımdan kanun yolları, somut olayda hukuka uygun bir şekilde ve adil karar verilip verilmediğinin denetiminin yapılması bakımından hak ve özgürlükleri koruyucu bir işleve sahip olmaktadır.

Anayasa'nın 2. maddesinde de belirtildiği üzere, Türkiye Cumhuriyeti bir hukuk devletidir. Dolayısıyla, hukuk devleti olmanın gereklerine uyulmak zorundadır. Bu gereklerden biri olan devletin üç erkinin hukuka bağlı olma zorunluluğu karşısında, yargının da hukuka bağlı olması gerekmektedir. Söz gelimi hakimin bir uyuşmazlık hakkında karar verirken; hukuka, kanuna, vicdana göre karar verip vermediği, kararlarında hakkaniyet ilkesini gözetip etmediği, bağımsız ve tarafsız davranıp davranmadığı denetlenmelidir. Yargının, yasama ve yürütme karşısında bağımsız olması gerektiği prensibinden hareketle denilebilir ki, bu denetimin yine yargı içinde yapılması hukuk devletine en uygun olanıdır. Dolayısıyla bu durum kanun yollarının,

\footnotetext{
57 YILMAZ, (2005), s. 60.

586545 sayılı Türk Ceza Kanunu ile Bazı Kanunlarda Değişiklik Yapılmasına Dair Kanun'un gerekçesi için bkz: http://www2.tbmm.gov.tr/d24/1/1-0918.pdf. (E.T. 08.01.2020).

59 YILMAZ, (2005), s. 60.

60 ÇAĞLAYAN, s. 6.
}

Ankara Hac1 Bayram Veli Üniversitesi Hukuk Fakültesi Dergisi C. XXIV, Y. 2020, Sa. 3441 
başka bir ifadeyle dereceli yargılamanın gereğini ortaya koymaktadır. Bu nedenle, hukuk devletinin bir gereği olarak dereceli yargılama bir haktır.

Anayasa'nın 36. maddesi, herkesin hak arama özgürlüğüne ve adil yargılanma hakkına sahip olduğunu hüküm altına almıştır. Kanun yolları da bir hak ve özgürlügün koruyucusu niteliğinde olduğundan ve taraflara haklarını temin yolu tanıdığından, dereceli yargılama hak arama özgürlüğü ve adil yargılanma hakkı kapsamında yer almaktadır. Bunların dışında, Anayasa'nın Danıştay'ı düzenlediği 155. maddesi, Danıştay'ın idari mahkemelerce verilen ve kanunun başka bir idari yargı merciine bırakmadığı karar ve hükümlerin son inceleme mercii olduğunu hükme bağlamaktadır. Bu düzenleme gereğince, ilk derece mahkemelerince verilen kararlara karşı kanun koyucunun takdirine bağlı olarak ya Danıştay'a ya da başka bir üst mahkemeye kanun yoluna başvuru imkanının kişilere tanınması zorunludur. Dolayısıyla, bu hüküm gereğince de dereceli yargılamanın bir hak olduğunu söylemek mümkündür.

Tüm bu açıklamalar 1şığında söylenebilir ki; kanun yoluna başvuru hakkı, hukuk devletinin, hak arama özgürlüğünün ve adil yargılanma hakkının bir parçasıdır. Bu hakkın sınırlanması mümkün olsa da bunun Anayasa'nın 13. maddesinde belirtilen esaslara uygun olarak yapilmas1 gerekmektedir. Sınırlama yapılırken ölçülülük ilkesinin gereklerine göre hareket edilmelidir. Genel olarak yargılama hukukumuza bakıldığında, tüm yargı kollarında kanun yoluna başvuru hakkının sınırlandırıldığı ve sınırlamanın da uyuşmazlığın miktar ve değerine bağlı olarak yapıldığı görülmektedir. Burada önemli olan husus, getirilecek meblağ sınırının çok yüksek tutulmamasıdır. İdari yargılama hukuku için konuya bakacak olursak; burada söz konusu sınır, yedi bin Türk Lirasıdır. Bu değerin altında kalan uyuşmazlıklar, ilk derece mahkemelerince verildikleri an kesinleşecektir. Başka bir ifadeyle, kanun yoluna başvuru hakk1 bu davalarda mümkün olmayacaktır. Bu rakam, hak arama özgürlügünü büyük ölçüde kısıtlamaktadır. Bu meblağın altında kalan davalarda kanun yolunun kabul edilmemesi demek, ilk derece mahkemesinin birçok kararının yanlış bir şekilde kesinleşmesine ve böylece adaletin zarar görmesine neden olmak demektir. Bu durum, toplumun adalet anlayışını zedeleyecek ve yargıya olan güveninin kırılmasına da yol açacaktır. Şüphesiz ki, ülkemizde yargı yerlerinin büyük bir iş yüküyle karşı karşıya kaldığı gerçeği bulunmaktadır. Bu nedenle, her türlü yargı kararının üst denetime tabi tutulması gerekmemektedir. Fakat bu rakamın idari yargı açısından bugün olduğu gibi yedi bin Türk Lirası değil, daha düşük tutulması gerekmektedir. Yargının iş yapabilirliğinin yanında kişilerin hak arama hürriyetlerinin feda edilmesi söz konusu olmamalıdır. $\mathrm{Bu}$ 
nedenle her iki husus arasındaki dengenin kurulması şart olup, sınırlamaların yerindeliği çok iyi araştırılmalıdır.

\section{KAYNAKÇA}

AKINCI, Müslüm: İdari Yargıda Adil Yargılanma Hakkı, Turhan Kitabevi, Ankara, 2008.

AKİL, Cenk: İstinaf, Yetkin Yayınları, Ankara, 2010.

AKKAN, Mine: ' 'Medeni Usul Hukukunda Etkin Hukuki Koruma', Medeni Usul ve İcra İflas Hukuku Dergisi, C. 3, S. 6, 2007, s. 29-68.

AKKAYA, Tolga: Medeni Usul Hukukunda İstinaf, Yetkin Yayınları, Ankara, 2009.

AKYILMAZ, Bahtiyar/SEZGINER, Murat/Kaya, Cemil: Türk İdari Yargılama Hukuku, Savaş Yayınevi, Ankara, 2018.

ALANGOYA, Yavuz: 'Anayasanın Medeni Usul Hukukuna Etkisi (1983 Milletlerarası Usul Kongresinin Bir Konusu)", Milletlerarası Hukuk ve Milletlerarası Özel Hukuk Bülteni, C. 1, Sa. 2, 1981, s. 1-4.

ALANGOYA, Yavuz: ' 'Kanun Yolunun Anayasal Temeli ve HUMK m. 427 Hükmü ile Kanun Yolu Kapatılmış Olan Kararlara Karşı Kanun Yoluna Müracaat İmkanı”, Türkiye Barolar Birliği Yayınları: Prof. Dr. Baki Kuru Armağanı, Ankara, 2004, s. 17-48.

ALANGOYA, Yavuz/YILDIRIM, M. Kamil/DEREN YILDIRIM, Nevhis: Medeni Usul Hukuku Esasları, 7. Baskı, Beta Basım Yayım Dağıtım, İstanbul, 2009.

ATALAY, Esra: '’Yargısal Temel Haklar', Prof. Şükrü Postacığlu'na Armağan, İzmir, 1997, s. 437-454.

AYDIN, Bihter: 'Türk İdari Yargı Düzeninde Mahkemeye Erişim Hakkı", Türkiye Adalet Akademisi Dergisi, Y. 4, S. 15, 2013, s. 271-296.

AYDINOĞLU: Zeynep Nihal: "İstinaf Kanun Yolunun İdari Yarg1lama Usulüne Başlıca Etkileri”, Türkiye Adalet Akademisi Dergisi, Y. 9, S. 34, 2018, s. 387-423.

BİLGE, Necip: Medeni Yargılama Hukukunda Karar Düzeltme, Ankara Üniversitesi Hukuk Fakültesi Yayınları, Ankara, 1973. 
ÇAĞLAYAN, Ramazan: İdari Yargıda Kanun Yolları (Kararlara Karşı Başvuru Yolları), 2. Baskı, Asil Yayıncılık, Ankara, 2008.

ÇİFTÇI, Murat Özgür: Medeni Yargılama Hukukunda İstinaf, 2. Bask1, Adalet Yayınevi, Ankara, 2016.

DEREN YILDIIRM, Nevhis: 'Kanun Yollarına Dair Bazı Düşünceler", Türkiye Barolar Birliği Yayınları: Medeni Usul ve İcra İflas Hukukçuları Toplantısı VI, Ankara, 2008, s. 3-17.

GİRITLİ, İsmet/BILLGEN, Pertev/AKGÜNER, Tayfun/BERK, Kahraman: İdare Hukuku, 6. Baskı, Der Yayınları, İstanbul, 2013.

GÖZLER, Kemal: 'Anayasa Değişikliklerinin Temel Hak ve Hürriyetlerin Sınırlandırılması Bakımından Getirdikleri ve Götürdükleri”, Ankara Barosu Dergisi, S. 3-4, 2001, s. 53-67.

GÖZLER, Kemal: Türk Anayasa Hukuku Dersleri, 24. Bask1, Ekin Basım Yayın Dağıtım, Bursa, 2019.

GÖZÜBÜYÜK, Şeref/GÖLCÜKLÜ: Feyyaz, Avrupa İnsan Hakları Sözleşmesi ve Uygulaması (AİHM İnceleme ve Yargılama Yöntemi), 10. Bask1, Turhan Kitabevi, Ankara, 2013.

GÖZÜBÜYÜK, Şeref/TAN, Turgut: İdari Yargılama Hukuku, 8. Bası, Turhan Kitabevi, Ankara, 2016.

GÜL, Cengiz/BİRTEK, Fatih: ''Hak Arama Özgürlüğü ve Türk Pozitif Hukukunda Yarg1 Yolu Kapalı İşlemler”, Erciyes Üniversitesi Hukuk Fakültesi Dergisi, C. II, S. 1-2, 2007, s. 3-41.

İNCEOĞLU, Sibel: İnsan Hakları Avrupa Mahkemesi Kararlarında Adil Yargılanma Hakkı (Kamu ve Özel Hukuk Alanlarında Ortak Yargısal İlkeler), 4. Baskı, Beta Basım Yayım Dağıtım, İstanbul, 2013.

KÖKÜSARI, İsmail: 'Hak Arama Özgürlüğü ve 2010 Anayasa Değişiklikleri”, Gazi Üniversitesi Hukuk Fakültesi Dergisi, C. XV, S. 1, 2011, s. 163-208.

ODYAKMAZ, Zehra: Türk İdari Yargılama Usulünde Kararlara Karşı Başvuru Yolları, Alfa Basım Yayım Dağıtım, İstanbul, 1993.

ÖKÇESİ, Hayrettin: 'Yargıtay'ın İş Yükünün Hafifletilmesinin Bir Aracı Olarak HUMK'nun 427. Maddesi Üzerine", Marmara Üniversitesi Hukuk Araştırmaları Dergisi, C. 2, 1987, s. 75-78. 
ÖZAY, İlhan: ' Kendine Özgü Bir Hukuk Devleti”, Danıştay Yayınları: I. Ulusal İdare Hukuku Kongresi (Birinci Kitap: İdari Yargı), Ankara, 1991, s. 115-137.

ÖZAY, İlhan: Günışı̆̆ında Yönetim, 3. Bask1, Filiz Kitabevi, İstanbul, 2017.

ÖZBUDUN, Ergun: Türk Anayasa Hukuku, 15. Bask1, Yetkin Yayınları, Ankara, 2014.

PEKCANITEZ, Hakan/ÖZEKES, Muhammet/AKKAN, Mine/KORKMAZ, Hülya: Pekcanıtez Usul-Medeni Usul Hukuku C. III, 15. Bask1, On İki Levha Yayıncılık, İstanbul, 2017.

ÖZTÜRK, Bahri: Nazari ve Uygulamalı Ceza Muhakemesi Hukuku, 3. Bask1, Seçkin Yayıncılık, Ankara, 2010.

SAĞLAM, Fazıl: Temel Hakların Sınırlanması ve Özü, Ankara Üniversitesi Siyasal Bilgiler Fakültesi Yayınları, Ankara, 1982.

TANRIVER, Süha: 'Hukuk Yarg1sı (Medeni Yarg1) Bağlamında Adil Yargilanma Hakkı”, Makalelerim I, Asil Yayıncılık, Ankara, 2005.

TEZCAN, Durmuş/ERDEM, M. Ruhan/SANCAKDAR, Oğuz/ÖNOK, R. Murat: İnsan Hakları El Kitabı, 4. Baskı, Seçkin Yayıncılık, Ankara, 2011.

ÜSTÜNDAĞ, Saim: Medeni Yargılama Hukuku C. I-II, 6. Bask1, Alfa Basım Yayım Dağıtım, İstanbul, 1997.

YILDIRIM, M. Kamil, 'İstinaf Sebepleri ve İlk Derece Mahkemesinde Hatalı Vakıa Tespiti”, Türkiye Barolar Birliği Yayınları: Medeni Usul ve İcra İflas Hukukçuları Toplantısı VI, Ankara, 2008, s. 89-131.

YILDIRIM, M. Kamil: Hukuk Devletinin Gereği İstinaf, Nesil Matbaacılık, İstanbul, 2000.

YILDIRIM, Turan/YASIN, Melikşah/KAMAN, Nur/ÖZDEMIR, H. Eyüp/ ÜSTÜN, Gül/OKAY TEKİNSOY, Özge: İdare Hukuku, 6. Bask1, On İki Levha Yayıncılık, İstanbul, 2017.

YILMAZ, Ejder: ' 'Hukuk Davalarında Yasa Yollarına Başvuru Hakk1 ve Bu Hakkın Sınırlandırılmasının Yerindeliği Sorunu", Türkiye Barolar Birliği Dergisi, S. 1, 1988, s. 131-155.

YILMAZ, Ejder: İstinaf, Genişletilmiş 2. Baskı, Yetkin Yayınları, Ankara, 2005. 
